\title{
Central nervous system activity of the methanol extracts of Helianthus annuus seeds in mice model
}

\author{
*Rubab Tarannum Islam ${ }^{1}$, Ahmed Tanjimul Islam², Mir Monir Hossain ${ }^{1}$ and Kishor Mazumder ${ }^{1}$ \\ ${ }^{1}$ Department of Pharmacy, University of Science and Technology Chittagong (USTC), Chittagong- 4202, Bangladesh \\ ${ }^{2}$ Medical officer, Department of Neurology, Chittagong Medical College and Hospital, Chittagong- 4203, Bangladesh
}

\begin{abstract}
Helianthus annuus seeds contain various chemical components and evaluate different biological activities. The present study was carried out to investigate the central nervous system (CNS) activity of methanolic extract of Helianthus annuus seeds in mice model. General behaviour, antidepressant activity and anxiolytic activity was observed. The results revealed that the methanol extract of Helianthus annuus seeds at 100 and $200 \mathrm{mg} / \mathrm{kg}$ caused a significant increase in the spontaneous activity (general behavioural profile), moderate increase in anxiolytic activity (light-dark box and elevated plus maze test) and remarkable increase in antidepressant activity (tail suspension test). The results suggest that methanol extract of Helianthus annuus exhibit significant antidepressant and moderate anxiolytic activity in tested animal models.
\end{abstract}

Key Words: Sunflower seeds, asteraceae, general behaviour, antidepressant activity, anxiolytic activity.

\section{INTRODUCTION}

The sunflower seed is the fruit of the sunflower (Helianthus annuus). The term "sunflower seed" is actually a misnomer when applied to the seed in its pericarp (hull). These seeds are usually pressed to extract their oil. It is a potential protein supplement for human diet. However, the primary use of sunflower seed is not for edible protein, it is for oil because certain attributes of sunflower seed oil have particularly attractive to the food industry. It is the rich source of vitamins especially vitamin E. Sterols, saponins, flavonoids, and unsaturated terpenoids are the main chemicals revealed in the phytochemical test of $H$. annuus. Flavonoids have antidepressant as well as mild anxiolytic properties. It has been reported that flavonoids and their synthetic derivatives selectively bind to the central benzodiazepine receptors, and shows anxiolytic and other benzodiazepine-like effects in animal model (Onasanwo et al., 2010). Flavonoids, saponin and terpinoids modulate the level of neurotransmitters such as serotonin, noradrenaline and dopamine (Patel et al., 2014). As there are limited numbers of research work has been carried out on $H$. annuus seed extract this study was conducted to investigate the central nervous system effects (general behaviours, antidepressant and anxiolytic effects) of methanolic extract of $H$. annuus by using mice model.

\section{MATERIALS AND METHODS}

\section{Animal}

Albino male Swiss mice (22-25g) obtained from BCSIR (Bangladesh Council of Scientific and Industrial Research) Chittagong, were used in the study. The mice were kept at constant temperature $\left(22 \pm 2^{\circ} \mathrm{C}\right)$ and 12-h light/12-h dark. Mice were fed standard laboratory food (Hind Lever diet pellets) and water was given ad libitum. Each animal was

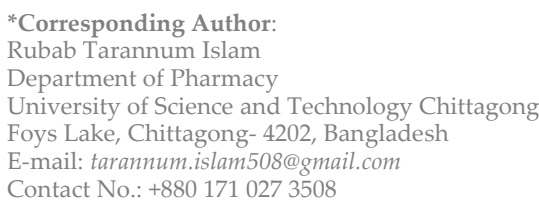

used once in the behaviour tests. The experimental protocols for this study were approved by the Institutional Ethical Committee of University of Science and Technology Chittagong (Reference: USTC/2015/1822/02) following the guidelines of Committee for the Purpose of Control and Supervision of Experiments on Animals (CPCSEA).

\section{Plant material and extraction}

$300 \mathrm{gm}$ dried powder of seed was weighed and taken in an aspirator (2.5L). Before placing powders into the aspirator, the jar was washed properly with acetone and then dried. $800 \mathrm{ml}$ of solvent i.e. methanol was added gradually. The container with its content was sealed \& kept for 20 days with occasional shaking \& stirring. The major portion of the extractable compounds of the plant materials were dissolved in the solvent. Then whole mixture was filtered through cotton wool and the filtrate was concentrated by evaporation in dry and clean air. It was kept for 15 days to get the final extract of the seed.

\section{Phytochemical screening}

Preliminary Phytochemical screening of the powdered seed was performed for the presence of alkaloids, carbohydrates, flavonoids, steroid and triterpenoids (Trease and Evans, 1995) (Table 1).

\section{Drugs and chemicals}

The following drugs were used: Diazepam, Imipramine, Propylene glycol and methanolic extract of Helianthus annuus seed.

\section{General behavioural profiles}

To determine the general behavioural profiles the test was performed by the method of Dixit and Varma (1976). Sixteen adult albino mice were divided in to four groups $(\mathrm{n}=4)$. Methanol extract of $H$. annuus was administered at the dose of 100 and $200 \mathrm{mg} / \mathrm{kg}$ (i.p.) for the first two groups of animals respectively. The last two groups were administered propylene glycol $(5 \mathrm{ml} / \mathrm{kg})$ as a vehicle control and diazepam $(5 \mathrm{mg} / \mathrm{kg})$ as a drug control. For their behavioural changes the animals were kept under 
Table 1: Chemical group test of Helianthus annuus seeds.

\begin{tabular}{ccc}
\hline Phytochemicals & Test & Inference \\
\hline Carbohydrates & Fehling's test & + \\
Alkaloids & Wagner's test & + \\
Flavonoids & Alcoholic test & + \\
Tannins & Ferric chloride test & - \\
Glycosides & Keller-Killiani test & - \\
Saponins & Foam test & - \\
Steroids & Libermann-Burchard test & + \\
Triterpenoids & Libermann-Burchard test & + \\
Gum & Molisch's test & - \\
\hline
\end{tabular}

observation, if any, at 30 min intervals in the first one hour and at the hourly intervals for the next 4 hour for the following parameters.

\begin{abstract}
Awareness, alertness and spontaneous activity
The awareness and alertness was recorded by visual measure of the animal's response when placed in a different position and its ability to orient itself without bumps or falls The normal behaviour at resting position was scored as mild movement(+), moderate movement $(++)$, strong movement $(+++)$ and extreme movement as $(++++)$. The spontaneous activity of the mice was recorded by placing the animal in a bell jar. It usually shows a significant degree of inquisitive behaviour. Moderate activity was scored as (++) and strong activity as (+++). If there is little motion, the score was (+), while if the animal sleeps, the score was (-). Excessive or very strong inquisitive activity like constant walking or running was scores as (++++). A similar test was performed with the same scoring, when the animals are removed from the jar and placed on a table (Ramanathan et al. 2008).
\end{abstract}

\section{Pinna Reflex}

It was measured by touching the centre of pinna with a hair or other fine instrument. The unaffected mouse withdraws from the irritating hair.

\section{Grip Strength}

It was measured by allowing the animal to grasp a pencil in the horizontal position and noting the time taken by the animal to drop the pencil on the table.

\section{Touch response}

The touch response was recorded by touching the mice with a pencil or forceps at the various part of the body (i.e., on the side of the neck, abdomen and groin).

\section{Pain response}

The pain response was graded when a small artery clamp was attached to the base of the tail, and response was noted.

\section{Anxiety model \\ Light-Dark Box Test}

Crawley and Goodwin procedure (1980) was done to assess the anxiolytic activity of the compounds (light-dark box test). The apparatus consisted of a light compartment and a dark compartment. Light dark box is a rectangular box of $46 \times 27 \times 30 \mathrm{~cm}(1 \times \mathrm{b} \mathrm{X} \mathrm{h})$, which is divided into 2 compartments. A central opening $(7 \times 7 \mathrm{~cm})$ on the floor level is placed for the joining of the two compartment. For this experiment, albino mice were divided into four groups, each group comprising of four animals. Vehicle (distilled water $10 \mathrm{ml} / \mathrm{kg}$ ), standard (diazepam $1 \mathrm{mg} / \mathrm{kg}$ ), and extract (100 and $200 \mathrm{mg} / \mathrm{kg}$ ) were administered p.o. One hour after administration, each mouse was placed individually in the illuminated part of the light/dark box. During the test session of $5 \mathrm{~min}$., latency (the time it takes for the animal to move into the dark compartment for the first time), number of entries into the light and dark compartments, total time spent in the light compartment were recorded.

\section{Elevated plus maze}

The Elevated plus maze is structured by two open arms and two closed arms (50X10 X40 cm each) elevated to a height of $50 \mathrm{~cm}$. Distilled water $(10 \mathrm{ml} / \mathrm{kg}), H$. annuus $(100$ and $200 \mathrm{mg} / \mathrm{kg})$ and diazepam $(1 \mathrm{mg} / \mathrm{kg})$ were administered p.o to 4 groups of 4 mice each. One hour posttreatment, each mouse was placed in turn in the centre of the maze facing one of the closed arms. The total time spent by each mouse in the open and closed arms of the maze and the number of entries was recorded for 5 minutes (Abidemi et al., 2012).

\section{Depression model \\ Tail suspension test}

Tail suspension test was done by the method described by Steru et al., (1985). The mice were suspended $60 \mathrm{~cm}$ above the surface of table with an adhesive tape placed $1 \mathrm{~cm}$ away from the tip of the tail. Immobility duration was recorded for the last 5 minutes. Mice were considered to be immobile when it did not show any movement of body and hanged passively. One hour prior to test, single administrations (p.o.) of $H$. annuus extract (100 and $200 \mathrm{mg} / \mathrm{kg}$ ) and Imipramine $(60 \mathrm{mg} / \mathrm{kg})$ was given.

\section{Statistical analysis}

The results were expressed as mean \pm S.E.M. Statistical software SPSS $®$ version 16 was used and ANOVA test was done for statistical analysis of difference between groups. The $\mathrm{p}$ values less than 0.05 were considered significant.

\section{RESULTS}

Response in general behavioural profile

$H$. annuus showed significant increase (++++) in grip strength and pain responses at dose of $200 \mathrm{mg} / \mathrm{kg}$. It also showed strong movement $(+++)$ response in spontenuous activity, pinna reflex and touch response at dose $200 \mathrm{mg} / \mathrm{kg}$. There was also moderate increase $(++)$ in awareness and alertness at dose $200 \mathrm{mg} / \mathrm{kg}$. However, the standard drug diazepam caused mild increase in all these responses compared with the methanol extract of $H$. annuus (Table 2).

\section{Response in Light-Dark box test}

$H$. annuus showed moderate increase in the latency of entry into the light box with peak effect produced at the dose of $200 \mathrm{mg} / \mathrm{kg}$ (72 \pm 0.85 seconds) compared to control $(34 \pm 5.63$ seconds). The effect at this dose was almost similar to that of diazepam $(84.00 \pm 16.29$ seconds). In respect of latency of entry into the light box and number of entries, the values for $H$. annuus showed moderately significant anxiolytic effect at the dose of both $100 \mathrm{mg} / \mathrm{kg}(63 \pm 0.62$ seconds) and $200 \mathrm{mg} / \mathrm{kg}$ (72 \pm 0.85 seconds) (Table 3).

\section{Response in Elevated plus maze}

$H$. annuus produced a significant increase in the time spent in the open arms with peak effect produced at the dose of $100 \mathrm{mg} / \mathrm{kg}(51 \pm 0.62$ seconds) relative to control $(30.23 \pm 0.62$ seconds). In respect of entry into open arms, 
Table 2: Response in general behaviour profile with $\mathrm{H}$. annuus seeds.

\begin{tabular}{|c|c|c|c|c|}
\hline \multirow{2}{*}{ Behaviour } & \multicolumn{2}{|c|}{ Extract (mg/kg) } & \multirow{2}{*}{$\begin{array}{c}\text { Diazepam } \\
5 \mathrm{mg} / \mathrm{kg}\end{array}$} & \multirow{2}{*}{$\begin{array}{c}\text { Propylene } \\
\text { glycol }\end{array}$} \\
\hline & 100 & 200 & & \\
\hline Awareness & + & ++ & + & - \\
\hline Alertness & + & ++ & + & - \\
\hline Spontaneous activity & + & +++ & + & - \\
\hline Pinna reflex & ++ & +++ & + & - \\
\hline Grip strength & ++ & ++++ & + & - \\
\hline Touch response & ++ & +++ & + & - \\
\hline Pain response & ++ & ++++ & + & - \\
\hline
\end{tabular}

Table 3: Response in light-dark box test with $H$. annuus seeds.

\begin{tabular}{cccc}
\hline Group & $\begin{array}{c}\text { Dosage } \\
\text { (mg/kg) }\end{array}$ & $\begin{array}{c}\text { Number of entry in } \\
\text { light box }\end{array}$ & $\begin{array}{c}\text { Time in light } \\
\text { box (seconds) }\end{array}$ \\
\hline Control & - & 4 & $34 \pm 1.65$ \\
Diazepam & 1 & 8 & $84 \pm 1.65$ \\
H. annuus & 100 & 5 & $63 \pm 0.62$ \\
& 200 & 6 & $72 \pm 0.85$ \\
\hline
\end{tabular}

Table 4: Response in tail suspension test with H. annuus seeds.

\begin{tabular}{ccc}
\hline Test Group & Dose $\mathbf{( m g / k g )}$ & $\begin{array}{c}\text { Immobility duration } \\
\text { (second) }\end{array}$ \\
\hline Control & - & $190.8 \pm 0.75$ \\
Imipramine & 60 & $30.2 \pm 0.64$ \\
H. annuus & 100 & $93 \pm 0.47$ \\
& 200 & $78 \pm 1.3$ \\
\hline
\end{tabular}

the extract at the dose of $100 \mathrm{mg} / \mathrm{kg}$ significantly $(\mathrm{p}<0.05)$ increased the number of entries compared to control. The number of entries into the closed arms was reduced by $H$. annuus at doses of 100 and $200 \mathrm{mg} / \mathrm{kg}$, and diazepam, with values of $90.7 \pm 0.64,80 \pm 1.08$, and $39.6 \pm 0.40$ respectively, compared to control $(110.7 \pm 0.70)$ which shows moderate anxiolytic activity (Figure 1).

\section{Response in tail suspension test}

$H$. annuus showed significant antidepressant activity $(\mathrm{p}<0.05)$ by decreasing the immobility time ( $H$. annuus $100 \mathrm{mg} / \mathrm{kg}$, $93 \pm 0.47 ; H$. annuus $200 \mathrm{mg} / \mathrm{kg}, 78 \pm 1.3$ ) as compared with Imipamine $(60 \mathrm{mg} / \mathrm{kg}, 30.2 \pm 0.64)$ and control (190.8 \pm 0.75$)$. There was significant difference between the effect of the various doses of $H$. annuus and that observed with control on the immobility time group when the mice were exposed to the tail suspension test (Table 4).

\section{DISCUSSION}

The present study investigated the central nervous system effects of the methanolic extract from Helianthus annuus seed in mice. To the best of our knowledge and for the first time, this research work on $H$. annuus produced significant antidepressant-like effects and moderate anxiolytic effects. When assessed in Tail Suspension Test (Steru et al., 1985), the fraction was able to induce antidepressant-like effects after oral administration of varying doses of $H$. annuus with the $100 \mathrm{mg} / \mathrm{kg}$ and $200 \mathrm{mg} / \mathrm{kg}$ dose showing the highest immobility. Based on these findings, it can be said that $H$. annuus which decreases the immobility time in tail suspension test is similar to the mechanism of fluoxetines via the serotonin system in depression.

$H$. annuus can also mediate its activity through the same mechanism as that of Imipramine. Imipramine belongs to the class of tricyclic antidepressant drugs

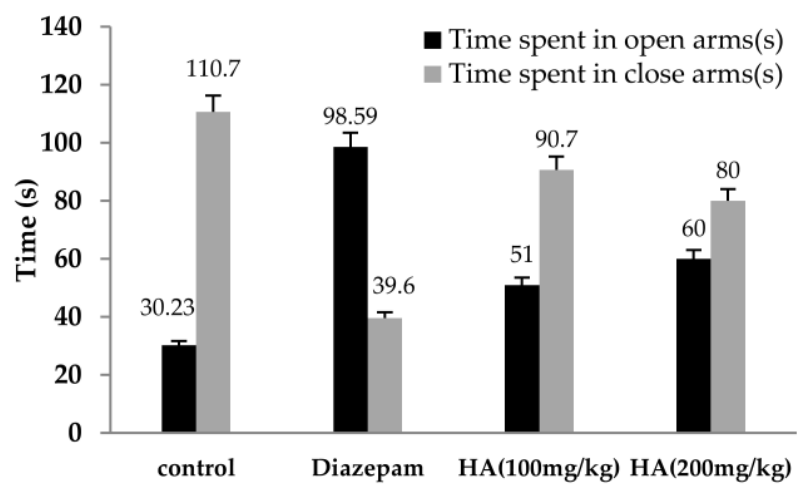

Figure 1: Response in Elevated plus maze test with $H$. annuus seeds. Data presented as average $\pm S E M, n=4$.

which blocks the reuptake of norepinephrine (NE) and 5hydroxytryptamine (5-HT) into their respective neurons. The light-dark and elevated plus maze tests which were used to explore the anxiolytic potentials of $H$. annuus, where $200 \mathrm{mg} / \mathrm{kg}$ dose showed moderate anxiolytic properties. Our study showed significant anxiolytic effect in light-dark box test (Young and Johnson, 1991) in compared to elevated plus maze test which showed moderate anxiolytic activity.

$H$. annuus was able to show a moderate anxiolyticlike properties in elevated plus maze test with the time the mice spent at the opened arm being more than the observed time with the mice that were given Diazepam. It is possible that each chemical constituents of the fraction exhibited the biological activity influencing on the neuro behaviours involving antidepressant activity.

However, the precise mechanism underlying $H$. annuus activity will still require further investigations. This might have been attained through its influence on the levels of monoamines. This research work has eliminated the involvement of neurotoxicity in the use of $H$. annuus for pharmacotherapy in anxiety and depression.

\section{CONCLUSION}

The results obtained in this study indicate that the methanol extract of the seed of Helianthus annuus have effect on central nervous system with significant antidepressant and moderate anxiolytic activity in different in vivo animal model. The medicinal values of the plant seed may be related to their constituent phytochemicals. So, further detailed investigations are needed to isolate and identify the active compounds present in the plant extract and its various fractions and their efficacy need to be done. It will help in the development of novel and safe drugs for the treatment of different types of central nervous system disorders.

\section{REFERENCES}

Abidemi J. Akindele, Hakeem A. Sanni, and Pamela C. Edeh.

(2012).Anxiolytic activity of aerial part hydroethanolic extract of Allium ascalonicum Linn. (Liliaceae) in mice.Functional Foods in Health and Disease, 2(11): 448-459.

Ali A, Venkat Rao N, Shalam M, Shivaraj Gouda T, Babu JM, Shantakumar SM: (2008).Anxiolytic activity of seed extract of Caesalpinia bonducella (Roxb) in laboratory animals. The Internet Journal of Pharmacology, $5(2)$.

Barua CC, Roy JD, Buragohian B, Barua AG, Borah P, Lahkar M: (2009). Anxiolytic effect of hydroethanolic extract of Drymaria cordata L Willd. Indian Journal of Experimental Biology, 47: 969-973. PMid:20329700

Belmaker RH, Agam G: (2008).Major depressive disorder. N Engl J Med.; 358:55-68. [DOI] 
Bilici M, Efe H, Köroglu MA, Uydu HA, Bekaroglu M, Deger O: (2001) Antioxidative enzyme activities and lipid peroxidation in major depression: alterations by antidepressant treatments. J Affec Disord; 64: 43-51. [DOI]

Bourin M, Hascoët M (2003).The mouse light/dark box test. European Journal of Pharmacology, 463(1-3): 55-65. [DOI]

Chattopadhyay D, Arunachalam G, Mandal SC, Bhadra R, Mandal AB: (2003). CNS activity of the methanol extract of Malloatus (Geist) Muell Arg. Leaf: An ethnomedicine of Onge. J Ethnopharmacol; 85: 99-105. [DOI]

Dixit VK, Varma KC. (1976). Effects of essential oil of leaves of Blumea lacera DC on central nervous system.Indian J Pharmacol. 18: 7-11.

Maribel H.R., Yolanda G.B., Sergio M., Gabriela D.V., Glauce S.B.V., Jaime T. and Guillermo R. ((2006). Antidepressant and anxiolytic effects of hydroalcoholic extract from Salvia elegans. Journal of Ethnopharmacology; 107; 53-58. [DOI]

Onasanwo S.A, Chatterjee M and Palit G. (2010) Antidepressant and Anxiolytic Potentials of Dichloromethane Fraction from Hedranthera barteri. Afr. J. Biomed. Res. 13: $76-81$
Pankti Patel, Kashmira J Gohil, Samaresh Pal Roy, Nikunj Patel (2014). Investigation of antidepressant and anxiolytic activity of curcumin given alone and in combination with amitriptyline in rats. Indian Journal of Research in Pharmacy and Biotechnology ISSN: 2321-5674.

Ramanathan Sambath Kumar, R. Shanmuga Sundram, P. Sivakumar, R. Nethaji, V. Senthil, N. Venkateswara Murthy and R. Kanagasabi.(2008) CNS activity of the methanol extracts of Careya arborea in experimental animal model. Bangladesh J Pharmacol; 3: 36-43.

Sakakibara H, Ishida K, Grundmann O, Nakajima JI, Seo S, Butterweck V, Minami Y, Saito S, Kawai Y, Nakaya Y, Terao J: (2006). Antidepressant effect of extracts from Ginkgo biloba leavesin behavioral models. Biol Pharm Bull; 29: 1767-70. [DOI]

Steru L., Chermat R., Thierry B. and Simon P. (1985). The tail suspension test: a new method for screening antidepressants in mice. Psychopharmacology 85: 367-370. [DOI]

Wesołowska A, Nikiforuk A, Stachowicz K, Tatarczyńska E: (2006). Effect of the selective 5-HT7 receptor antagonist SB 269970 in animal models of anxiety and depression. Neuropharmacology; 51:578-86. [DOI]

Young R. and Johnson D.N. (1991). A fully automated light/dark apparatus useful for comparing anxiolytic agents. Pharmacology Biochemistry and Behaviour; 40, 739-743. [DOI] 